\title{
Exploitation of Promising Hybrids on the Basis of Heterosis and Quality Parameters of Pigeonpea (Cajanus cajan (L.) Millsp.)
}

\author{
Priyanka S. Gaikwad*, Dipali P. Thakare and S.P. Mehtre \\ Department of Agricultural Botany, Vasantrao Naik Marathwada Krishi Vidyapeeth, \\ Parbhani, Maharashtra, India \\ *Corresponding author
}

\section{A B S T R A C T}

\section{Keywords}

Pigeonpea

(Cajanus cajan (L.)

Millsp.)

Heterosis.

Article Info

Accepted:

20 February 2017

Available Online:

10 March 2017

\begin{abstract}
The field investigation done at the experimental farm of Department of Agricultural Botany, Vasantrao Naik Marathwada Krishi Vidyapeeth, Parbhani, Maharashtra to understand the magnitude of standard heterosis and dal quality parameters in newly developed CGMS (Cytoplasmic Genic male Sterility) based hybrids at International Crops Research Institute for the Semi-Arid Tropics (ICRISAT), Patancheru, Hyderabad. Total eighteen hybrids along with three checks (Asha, Maruti and ICPH 2671) were planted in randomized block design (RBD) with three replications during Kharif season. The results of the current investigation indicated that out of eighteen hybrids, seven promising hybrids (ICPH 3381, ICPH 2751, ICPH 2673, ICPH 3341, ICPH 3337, ICPH 3933 and ICPH 3359) were identified on the basis of standard heterosis $(46.37 \%, 45.19 \%, 44.08 \%$, $43.22 \%, 42.09 \%, 37.67 \%$ and $30.00 \%$ respectively) over the higher grain yield performing check Maruti. Significant variation observed for the dal quality parameters among the hybrids except for protein content.
\end{abstract}

\section{Introduction}

Pigeonpea (Cajanus cajan (L.) Millsp.) is one of the major pulse crop of the tropics and subtropics endowed with several unique characteristics, it find an important place in the farming system adopted by small holders in large number of developing countries. During the last four decades, the total area under pulses remained stagnant (22 to 24 million ha) with stable production of 12 to 14 million tonnes which yearly lead to shortage of $d a l$ due to increasing population in India. Due to stagnant production, the net availability of pulses has come down from 60 $\mathrm{gm} /$ day/person in 1951 to $31 \mathrm{gm} /$ day/person (Indian Council of Medical Research recommends $65 \mathrm{gm} / \mathrm{day} /$ person) in 2008. The per capita availability of protein in the country is one-third of its requirement and if production of major pulses is not increased significantly, the problem of malnutrition in large section of vegetarian population will further aggravate (Saxena and Nadarajan, 2010). Thus, there is an urgent need to increase the production of pulses to meet the increasing demand by adopting the appropriate production technologies.

Exploitation of hybrid vigour is quite possible in cross pollinated crops. However, pigeonpea is a grain legume crop with a moderate level of cross pollination (20-70\%), which is mainly added by insect pollinators. 
As the first step, hybrids based on genetic male sterility (GMS) were developed in pigeonpea. Considering the limitations in large scale hybrid seed production encountered due to genetic male sterility. Pigeonpea experimental hybrids have been developed by using the CMS-based hybrid technology. The CMS hybrid overcomes the limitations of an earlier generation pigeonpea hybrids. Similarly, it is also essential to improve nutritional qualities of pigeonpea $d a l$, so that consumption of quality can fulfill the requirement.

\section{Materials and Methods}

The field investigation done at the experimental farm of Department of Agricultural Botany, Vasantrao Naik Marathwada Krishi Vidyapeeth, Parbhani, Maharashtra to study the magnitude of standard heterosis and dal quality parameters in newly developed CGMS (Cytoplasmic Genic male Sterility) based hybrids at International Crops Research Institute for the Semi-Arid Tropics (ICRISAT), Patancheru, Hyderabad. In the current study, 18 hybrids (ICPH-3462, ICPH-3464, ICPH-2740, ICPH3477, ICPH-3491, ICPH-3461, ICPH-3762, ICPH-2673, ICPH-3341, ICPH- 3472, ICPH3340, ICPH-3337, ICPH-3359, ICPH-3494, ICPH-3497, ICPH-3933, ICPH-3381, and ICPH-2751) was sown along with check ICPH-2671, Maruti, and Asha in randomized block design (RBD) with three replications. The inter and intra spacing was $75 \mathrm{~cm}$ and 30 cm respectively.

The seed material was treated with tetramethylthiuramdisulphide @ $3 \mathrm{~g} / \mathrm{kg}$ prior to sowing to prevent fungal disease infestations while germination. Recommended package of cultural management practices and plant protection measures were adopted to raise a healthy crop. Data were recorded on five randomly selected plants for yield and its associated parameters. Apart from these quantitative characters, data were recorded on eleven quality parameters in hybrids. The collected data were subjected to statistical analysis to understand the magnitude of standard heterosis along with performance for quality parameters.

\section{Results and Discussion}

Analysis of variance for yield and its associated characters indicated that genotypes (treatments) had highly significant differences for the entire yield and its related parameters except plant height $(\mathrm{cm})$ and 100 seed weight (g) (Table 1). The results of the standard heterosis indicated that among eighteen hybrids, ICPH 3381 recorded highly significant positive standard heterosis over the check Maruti for grain yield per plant (46.37 $\%$ ) along with the higher mean performance (56.94 g). Similarly, the hybrid ICPH 3381 obtained highly significant positive standard heterosis along with highest mean performance for number of primary braches per plant $(111.11 \%, 9.5$ resp.), number of secondary branches per plant $(43.47 \%, 16.6$ resp.), number of pods per plant $(43.47 \%$, 181.55 resp.) and number of seeds per pod (11.11\%, 4.50 resp.). The another promising hybrid ICPH 2751 showed highly significant desirable standard heterosis for yield per plant $(45.19 \%)$ with higher mean performance at $56.48 \mathrm{~g}$ as compared to other hybrids. The hybrids recorded significant positive heterosis for other yield associated characters like number of primary braches per plant $(133.33 \%)$, number of pods per plant (23.96\%), number of seeds per pod $(14.81 \%)$ along with the desirable mean performance at $10.50,196.70$, and 4.65 respectively.

With respect to hybrid ICPH 2673 recorded significantly higher heterosis for grain yield per plant $(44.08 \%)$ along with significantly 
higher number primary branches per plant (44.44\%), number secondary branches per plant $(31.00 \%)$ and number of pods per plant $(6.41 \%)$ with the better mean performance at $56.05 \mathrm{~g}, 6.5,15.50$, and 168.85 respectively. Another promising hybrid ICPH 3341 identified on the basis of higher standard heterosis for grain yield per plant $(43.22 \%)$ and associated characters like number of primary branches per plant $(63.00 \%)$, number of secondary branches per plant $(34.78 \%)$ and number of pods per plant $(6.41 \%)$ with good mean performance at $55.71 \mathrm{~g}, 7.94,13.50$, and 175.90 respectively.

Similarly, ICPH 3337 obtained significantly higher heterosis for grain yield per plant (42.09) and its associated parameters like number of primary branches per plant (37.00\%), number of secondary branches per plant (33.34\%), and number of pods per plant $(8.43 \%)$ with good mean performance at $55.27 \mathrm{~g}, 6.17,14.50,172.05$ respectively. Likewise, other promising performing hybrid ICPH 3933 recorded significantly higher standard heterosis over the check Maruti for grain yield per plant $(37.67 \%)$ with higher heterosis for number of primary branches per plant $(81.44 \%)$, number of secondary branches per plant $(40.56 \%)$ and number o pods per plant $(12.93 \%)$ along with mean performance of $53.55 \mathrm{~g}, 8.17,16.17$, and 179.20 respectively.

Another, promising hybrid ICPH 3359 showed significantly higher heterosis (Table 3) over the check Maruti for grain yield per plant $(30.00 \%)$ along with number primary branches per plant $(17.77 \%)$ and number of pods per plant $(5.18 \%)$. Similarly the hybrid 3359 recorded good higher grain yield $(50.57$ $\mathrm{g})$, number of primary branches per plant (5.30), and number of seeds per pod (166.90) on mean performance basis (Table 4). Patel et al., (2008), Phad et al., (2009), Sarode et al., (2009) higher test weight, number of primary branches, number of secondary branches in pigeonpea hybrid which are yield contributing characters.

\section{Dal quality parameters}

The variation due to the treatment effect showed highly significant variation for all the characters except dehulling (\%) and protein content $(\%)$ (Table 1).

With respect to dehulling (\%), the range of dehulling (\%) was with 55.75 to 75.06 per cent with an average value of 66.55 per cent. The hybrid ICPH 3762 (75.06\%) with the highest dehulling per cent followed by ICPH $3491(73.85 \%)$ and the hybrid ICPH 2673 $(55.75 \%)$ was with lowest dehulling per cent (Table 5). Ethiwe and Reichert (1986) reported less variation in dehulling characters. In pigeonpea per cent intact seeds were generally more in comparison to cowpea cultivars and mostly it was intermediate. Same has been observed in this study also. However, Weight of $250 \mathrm{CC}$ of seed was ranged from 245.08 to $267.96 \mathrm{~g}$ with an average value of $253.22 \mathrm{~g}$ among eighteen hybrids, ICPH 3762 obtained maximum weight of $250 \mathrm{CC}$ of seed $(267.96 \mathrm{~g})$ and ICPH 3491 showed lowest weight of $250 \mathrm{CC}$ of seed $(245.08 \mathrm{~g})$.

Likewise, the range of size of $d a l$ was 0.255 to $0.345 \mathrm{~cm}$ with an average value of 0.301 $\mathrm{cm}$. The hybrid ICPH 3359 was with highest value for size of dal $(0.345 \mathrm{~cm})$ followed by ICPH $3337(0.330 \mathrm{~cm})$ and the hybrids ICPH 3491 and ICPH 3497 obtained lowest value for size of dal $(0.255 \mathrm{~cm}$ and $0.255 \mathrm{~cm}$ respectively). The medium sized and thick dal is easily cooked than thin dal. Big sized dal has taken the maximum time for cooking. Big sized dal absorbed more water thereby resulting in maximum increase in weight of cooked dal as compared to the small and medium sized dal. 
Table.1 Analysis of variance for yield and yield contributing characters in ICRISAT Pigeonpea hybrids

\begin{tabular}{|c|c|c|c|c|c|c|c|c|c|c|c|}
\hline \multirow{2}{*}{$\begin{array}{l}\text { Source of } \\
\text { variation }\end{array}$} & \multirow[t]{2}{*}{ d. f. } & \multicolumn{10}{|c|}{ Mean sum of squares } \\
\hline & & $\begin{array}{l}\text { Fertility } \\
(\%)\end{array}$ & $\begin{array}{c}\text { Days to } \\
50 \% \\
\text { flowering }\end{array}$ & $\begin{array}{l}\text { Days to } \\
\text { maturity }\end{array}$ & $\begin{array}{l}\text { Plant } \\
\text { height } \\
(\mathrm{cm})\end{array}$ & $\begin{array}{c}\text { Number of } \\
\text { primary } \\
\text { branches per } \\
\text { plant }\end{array}$ & $\begin{array}{c}\text { Number of } \\
\text { secondary } \\
\text { branches per } \\
\text { plant }\end{array}$ & $\begin{array}{c}\text { Number of } \\
\text { pods per } \\
\text { plant }\end{array}$ & $\begin{array}{l}\text { Number of } \\
\text { seeds per } \\
\text { pod }\end{array}$ & $\begin{array}{c}100 \text { seed } \\
\text { weight } \\
(\mathrm{g})\end{array}$ & $\begin{array}{l}\text { Yield per } \\
\text { plant (g) }\end{array}$ \\
\hline & & 1 & 2 & 3 & 4 & 5 & 6 & 7 & 8 & 9 & 10 \\
\hline Replications & 1 & 07.570 & 05.357 & 22.881 & 102.77 & 0.396 & 0.172 & 007.43 & 0.040 & 0.228 & 034.853 \\
\hline Treatments & 20 & $36.117 * *$ & $34.207 * *$ & $37.500 * *$ & 297.10 & $9.292 * *$ & $9.325 * *$ & $347.61 * *$ & $0.174 * *$ & 1.235 & $197.000 * *$ \\
\hline Error & 20 & 10.491 & 02.907 & 02.581 & 165.47 & 0.0427 & 0.154 & 000.91 & 0.018 & 0.877 & 006.871 \\
\hline
\end{tabular}

Note: $*$ and $* *$ indicates significance at 5 and 1 per cent level respectively.

Table.2 Analysis of variance for dal quality parameters in ICRISAT Pigeonpea hybrids

\begin{tabular}{|c|c|c|c|c|c|c|c|c|c|c|c|c|}
\hline \multirow{2}{*}{$\begin{array}{l}\text { Source of } \\
\text { variation }\end{array}$} & \multirow[t]{2}{*}{ d. f. } & \multicolumn{11}{|c|}{ Mean sum of squares } \\
\hline & & $\begin{array}{c}\text { Dehulling } \\
(\%)\end{array}$ & $\begin{array}{l}\text { Weight of } \\
250 \mathrm{CC} \\
\text { seed }(\mathrm{g})\end{array}$ & $\begin{array}{l}\text { Size of dal } \\
\quad(\mathrm{cm})\end{array}$ & $\begin{array}{l}\text { Thickness } \\
\text { of dal (cm) }\end{array}$ & $\begin{array}{c}\text { Number } \\
\text { of dal in } \\
10 \mathrm{~g} \\
\end{array}$ & $\begin{array}{l}\text { Volume } \\
\text { of } 10 \mathrm{~g} \mathrm{of} \\
\text { dal (cc) }\end{array}$ & $\begin{array}{c}\text { Weight of } \\
\text { cooked } \\
\text { dal }(g)\end{array}$ & $\begin{array}{l}\text { \% increase } \\
\text { in volume }\end{array}$ & $\begin{array}{l}\text { \% increase } \\
\text { in weight }\end{array}$ & $\begin{array}{c}\text { Time taken } \\
\text { for cooking } \\
(\mathrm{m}+\mathrm{s})\end{array}$ & $\begin{array}{c}\text { Protein } \\
\text { content } \\
(\%)\end{array}$ \\
\hline & & 1 & 2 & 3 & 4 & 5 & 6 & 7 & 8 & 9 & 10 & 11 \\
\hline Replications & 1 & 00.301 & 00.728 & 0.00019 & 0.000009 & 001.16 & 0.023 & 1.911 & 001.928 & 000.095 & 027.524 & 0.302 \\
\hline Treatments & 20 & 23.689 & $44.902 * *$ & $0.00096 * *$ & $0.000650 * *$ & $782.02 * *$ & $0.866 * *$ & $3.059 * *$ & $259.780 * *$ & $361.460 * *$ & $180.900 * *$ & 5.006 \\
\hline Error & 20 & 00.075 & 01.072 & 0.00005 & 0.000069 & 002.66 & 0.016 & 0.209 & 000.194 & 000.795 & 016.624 & 0.173 \\
\hline
\end{tabular}


Table.3 Standard heterosis for various yield and its associated traits over the check Maruti

\begin{tabular}{|c|c|c|c|c|c|c|c|}
\hline Sr. No. & Hybrids & $\begin{array}{c}\text { No. of primary } \\
\text { branches per } \\
\text { plant }\end{array}$ & $\begin{array}{c}\text { No. of secondary } \\
\text { branches per plant }\end{array}$ & $\begin{array}{l}\text { No. of pods } \\
\text { per plant }\end{array}$ & $\begin{array}{c}\text { No. of seeds per } \\
\text { pod }\end{array}$ & $\begin{array}{c}100 \text { seed } \\
\text { weight }(\mathrm{g})\end{array}$ & $\begin{array}{l}\text { Yield per } \\
\text { plant }(g)\end{array}$ \\
\hline 1 & ICPH 3462 & -29.66 & -02.91 & -7.41 & 1.23 & 6.27 & -22.04 \\
\hline 2 & ICPH 3464 & -09.66 & $13.60 * *$ & -0.92 & -4.93 & 7.95 & -0.47 \\
\hline 3 & ICPH 2740 & $14.77 * *$ & $26.08 * *$ & $1.87 * *$ & 2.46 & 0.83 & 5.50 \\
\hline 4 & ICPH 3477 & -31.88 & -02.91 & -6.75 & -1.23 & $17.99 *$ & -17.67 \\
\hline 5 & ICPH 3491 & -15.22 & $08.69 *$ & -5.11 & 2.46 & 7.11 & -12.89 \\
\hline 6 & ICPH 3461 & -32.44 & $11.43 * *$ & -4.23 & 0.00 & -2.92 & -27.64 \\
\hline 7 & ICPH 3762 & -05.88 & $22.87 * *$ & -1.27 & -2.46 & -2.51 & 0.87 \\
\hline 8 & ICPH 2673 & $44.44 * *$ & $31.00 * *$ & $6.41 * *$ & -22.22 & -8.36 & $44.08 * *$ \\
\hline 9 & ICPH 3341 & $63.00 * *$ & $34.78 * *$ & $10.85 * *$ & -8.64 & -0.41 & $43.22 * *$ \\
\hline 10 & ICPH 3472 & -07.44 & $17.39 * *$ & -0.48 & -6.17 & 2.51 & -0.25 \\
\hline 11 & ICPH 3340 & 07.00 & $23.17 * *$ & $1.53 * *$ & 2.46 & 4.60 & 4.28 \\
\hline 12 & ICPH 3337 & $37.00 * *$ & $33.34 * *$ & $8.43 * *$ & 1.23 & -4.18 & $42.09 * *$ \\
\hline 13 & ICPH 3359 & $17.77 * *$ & 05.78 & $5.18 * *$ & -3.70 & 0.41 & $30.00 * *$ \\
\hline 14 & ICPH 3494 & -29.66 & $26.08 * *$ & -5.84 & -1.23 & 14.64 & -13.07 \\
\hline 15 & ICPH 3497 & $14.77 * *$ & $34.78 * *$ & $4.57 * *$ & -2.64 & -6.22 & $14.65^{*}$ \\
\hline 16 & ICPH 3933 & $81.44 * *$ & $40.56 * *$ & $12.93 * *$ & 0.00 & -5.85 & $37.67 * *$ \\
\hline 17 & ICPH 3381 & $111.11 * *$ & $43.47 * *$ & $14.42 * *$ & $11.11 * *$ & 10.87 & $46.37 * *$ \\
\hline \multirow[t]{4}{*}{18} & ICPH 2751 & $133.33 * *$ & 5.78 & $23.96 * *$ & $14.81 * *$ & 0.83 & $45.19 * *$ \\
\hline & $\mathbf{S E} \pm$ & 0.146 & 0.278 & 0.54 & 0.10 & 0.66 & 1.85 \\
\hline & $\mathrm{CD}$ at $5 \%$ & 0.430 & 0.819 & 1.60 & 0.28 & 1.95 & 5.46 \\
\hline & CD at $1 \%$ & 0.588 & 1.119 & 2.19 & 0.38 & 2.66 & 7.45 \\
\hline
\end{tabular}

Note: $*$ significant at $5 \%$ and $* *$ significant at $1 \%$ 
Table.4 Mean performance of ICRISAT hybrids for various yield and yield associated parameters

\begin{tabular}{|c|c|c|c|c|c|c|c|}
\hline Sr. No. & Genotypes & $\begin{array}{l}\text { Number of primary } \\
\text { branches per plant }\end{array}$ & $\begin{array}{c}\text { Number of } \\
\text { secondary } \\
\text { branches per } \\
\text { plant } \\
\end{array}$ & $\begin{array}{c}\text { Number of pods } \\
\text { per plant }\end{array}$ & $\begin{array}{c}\text { Number of } \\
\text { seeds per pod }\end{array}$ & $\begin{array}{c}100 \text { seed weight } \\
\text { (g) }\end{array}$ & $\begin{array}{c}\text { Yield per plant } \\
\text { (g) }\end{array}$ \\
\hline 1 & ICPH 3462 & 3.17 & 11.17 & 146.9 & 4.1 & 12.7 & 30.32 \\
\hline 2 & ICPH 3464 & 4.07 & $13.07 * *$ & 157.2 & 3.85 & 12.9 & 38.71 \\
\hline 3 & ICPH 2740 & $5.17 * *$ & $14.50 * *$ & $161.65^{* *}$ & 4.15 & 12.05 & 41.04 \\
\hline 4 & ICPH 3477 & 3.07 & 11.17 & 147.95 & 4 & $14.10^{*}$ & 32.02 \\
\hline 5 & ICPH 3491 & 3.82 & $12.50 *$ & 150.55 & 4.15 & 12.8 & 33.88 \\
\hline 6 & ICPH 3461 & 3.04 & $12.82 * *$ & 151.95 & 4.05 & 11.6 & 28.14 \\
\hline 7 & ICPH 3762 & 4.24 & $14.13 * *$ & 156.65 & 3.95 & 11.65 & 39.24 \\
\hline 8 & ICPH 2673 & $6.5^{* *}$ & $15.50 * *$ & $168.85^{* *}$ & 3.15 & 10.95 & $56.05 * *$ \\
\hline 9 & ICPH 3341 & $7.34 * *$ & $13.50 * *$ & $175.90^{* *}$ & 3.7 & 11.9 & $55.71 * *$ \\
\hline 10 & ICPH 3472 & 4.17 & $14.17 * *$ & 157.9 & 3.8 & 12.25 & 38.8 \\
\hline 11 & ICPH 3340 & 4.82 & $15.34 * *$ & $161.10 * *$ & 4.15 & 12.5 & 40.56 \\
\hline 12 & ICPH 3337 & $6.17 * *$ & $14.50 * *$ & $172.05^{* *}$ & 4.1 & 11.45 & $55.27 * *$ \\
\hline 13 & ICPH 3359 & $5.30 * *$ & 12.17 & $166.90 * *$ & 3.9 & 12 & $50.57 * *$ \\
\hline 14 & ICPH 3494 & 3.17 & $14.40 * *$ & 149.4 & 4 & 13.7 & 33.81 \\
\hline 15 & ICPH 3497 & $5.17 * *$ & $15.50 * *$ & $162.75^{* *}$ & 3.95 & 11.2 & $44.60 *$ \\
\hline 16 & ICPH 3933 & $8.17 * *$ & $16.17 * *$ & $179.20 * *$ & 4.05 & 12.65 & $53.55 * *$ \\
\hline 17 & ICPH 3381 & $9.50 * *$ & $16.50 * *$ & $181.55^{* *}$ & $4.50 * *$ & 13.25 & $56.94 * *$ \\
\hline 18 & ICPH 2751 & $10.50 * *$ & 12.17 & $196.70 * *$ & $4.65^{* *}$ & 11.85 & $56.48 * *$ \\
\hline 19 & ICPH 2671(ch) & 3.5 & $13.50^{* *}$ & 150.3 & 3.75 & 12.15 & 33.84 \\
\hline 20 & Maruti (ch) & 4.5 & 11.5 & 158.67 & 4.05 & 11.95 & 38.89 \\
\hline \multirow[t]{5}{*}{21} & Asha (ch) & 3.17 & 7 & 148.05 & 3.85 & 12.25 & 32.16 \\
\hline & G. mean & 5.17 & 13.392 & 162.01 & 3.99 & 12.28 & 42.41 \\
\hline & $\mathrm{SE} \pm$ & 0.146 & 0.278 & 0.54 & 0.1 & 0.66 & 1.85 \\
\hline & $\mathrm{CD}$ at $5 \%$ & 0.43 & 0.819 & 1.6 & 0.28 & 1.95 & 5.46 \\
\hline & $\mathrm{CD}$ at $1 \%$ & 0.588 & 1.119 & 2.19 & 0.38 & 2.66 & 7.45 \\
\hline
\end{tabular}

Note: * significant at $5 \%$ and $* *$ significant at $1 \%$ 
Table.5 Mean performance of ICRISAT hybrids for various dal quality parameters

\begin{tabular}{|c|c|c|c|c|c|c|c|c|c|c|c|c|}
\hline $\begin{array}{l}\text { Sr. } \\
\text { No. }\end{array}$ & Name of hybrid & Dehulling (\%) & $\begin{array}{c}\text { Weight of } \\
250 \mathrm{CC} \\
\text { seed }\end{array}$ & $\begin{array}{l}\text { Size of dal } \\
(\mathrm{cm})\end{array}$ & $\begin{array}{c}\text { Thickness } \\
\text { of dal }(\mathrm{cm})\end{array}$ & $\begin{array}{l}\text { Number of } \\
\text { dal in } 10 \mathrm{~g}\end{array}$ & $\begin{array}{c}\text { Volume of } \\
10 \mathrm{~g} \text { of dal } \\
\text { (cc) }\end{array}$ & $\begin{array}{l}\text { Weight of } \\
\text { cooked dal } \\
\text { (g) }\end{array}$ & $\begin{array}{l}\text { \% increase } \\
\text { in volume }\end{array}$ & $\begin{array}{l}\text { \% increase } \\
\text { in weight }\end{array}$ & $\begin{array}{c}\text { Time taken } \\
\text { for cooking } \\
(\mathbf{m}+\mathbf{s})\end{array}$ & Protein content $(\%)$ \\
\hline 1 & ICPH 3462 & $66.61(54.69)$ & 253.26 & 0.27 & 0.17 & 264 & 13.15 & 30.65 & 133.07 & 206.5 & 60 & $16.83(24.21)$ \\
\hline 2 & ICPH 3464 & $58.70(50.00)$ & 250.6 & 0.29 & 0.19 & 244 & 14.15 & 28.8 & 100.77 & 182.5 & 35.5 & $18.15(25.21)$ \\
\hline 3 & ICPH 2740 & $59.65(50.55)$ & 254.7 & 0.3 & 0.19 & 249.5 & 15.25 & 31.3 & 107.04 & 216.5 & 42.5 & $18.11(25.18)$ \\
\hline 4 & ICPH 3477 & $71.03(57.43)$ & 250.35 & 0.32 & 0.21 & 229.5 & 13.35 & 30.7 & 127.6 & 201.5 & 37.5 & $17.82(24.96)$ \\
\hline 5 & ICPH 3491 & $73.85(59.24)$ & 245.08 & 0.25 & 0.18 & 242.5 & 15.35 & 31.85 & 104.36 & 213.5 & 56 & $22.11(28.04)$ \\
\hline 6 & ICPH 3461 & $65.11(53.79)$ & 255.96 & 0.29 & 0.2 & 219.5 & 14.25 & 28.85 & 100.06 & 185.5 & 42.5 & $19.795(26.41)$ \\
\hline 7 & ICPH 3762 & $75.06(60.03)$ & 267.96 & 0.3 & 0.21 & 245.5 & 14.45 & 29.7 & 102.59 & 193.5 & 49 & $16.38(23.86)$ \\
\hline 8 & ICPH 2673 & $55.75(48.29)$ & 245.93 & 0.29 & 0.21 & 265.5 & 14.85 & 31.25 & 118.06 & 217.5 & 49.5 & $13.81(21.80)$ \\
\hline 9 & ICPH 3341 & $57.81(49.48)$ & 250.39 & 0.3 & 0.22 & 254 & 15.05 & 29.75 & 93.75 & 193.5 & 42.5 & $19.165(25.95)$ \\
\hline 10 & ICPH 3472 & $65.81(54.21)$ & 252.71 & 0.3 & 0.19 & 280.5 & 15.55 & 29.25 & 84.05 & 186.5 & 42.5 & $20.60(26.98)$ \\
\hline 11 & ICPH 3340 & $71.960(58.01)$ & 251.29 & 0.31 & 0.19 & 241.5 & 15.25 & 31.05 & 102.06 & 208.5 & 64 & $18.58(25.52)$ \\
\hline 12 & ICPH 3337 & 69.97 (56.76) & 256.36 & 0.33 & 0.22 & 254 & 15.35 & 31.95 & 107.96 & 220.5 & 37.5 & $21.06(27.31)$ \\
\hline 13 & ICPH 3359 & $70.64(57.18)$ & 250.35 & 0.345 & 0.215 & 265 & 15.5 & 31.65 & 103.05 & 218.5 & 42.5 & 21.45 (27.58) \\
\hline 14 & ICPH 3494 & $66.08(54.37)$ & 251.8 & 0.295 & 0.205 & 269 & 15.05 & 32.08 & 113.41 & 223.5 & 65.5 & $19.125(25.92)$ \\
\hline 15 & ICPH 3497 & $68.64(55.93)$ & 256.95 & 0.255 & 0.185 & 229 & 14.55 & 29.75 & 100.71 & 193.5 & 53.5 & $18.58(25.52)$ \\
\hline 16 & ICPH 3933 & $71.03(57.42)$ & 252.95 & 0.29 & 0.225 & 244.5 & 14.45 & 28.75 & 96 & 184.5 & 57.5 & 20.55 (26.95) \\
\hline 17 & ICPH 3381 & $59.02(50.19)$ & 258.75 & 0.305 & 0.225 & 249.5 & 14.75 & 29.1 & 95.71 & 189.5 & 42.5 & $16.80(24.19)$ \\
\hline 18 & ICPH 2751 & $62.71(52.36)$ & 250.6 & 0.315 & 0.17 & 281 & 15.05 & 30.65 & 100.91 & 200.5 & 52.5 & $15.44(23.13)$ \\
\hline 19 & ICPH 2671 & $66.05(54.35)$ & 253.76 & 0.295 & 0.175 & 267.5 & 14.15 & 30.35 & 115.9 & 201 & 64 & $19.705(26.34)$ \\
\hline 20 & Maruti (ch) & $71.19(57.53)$ & 252.71 & 0.315 & 0.205 & 302 & 14.65 & 32.35 & 114.99 & 218.5 & 42.5 & $16.76(24.16)$ \\
\hline \multirow[t]{5}{*}{21} & Asha (ch) & $71.01(57.41)$ & 255.05 & 0.325 & 0.215 & 235.5 & 15.25 & 32.5 & 110.81 & 210.5 & 57.5 & 20.58 (26.97) \\
\hline & G. mean & $66.559(54.73)$ & 253.22 & 0.301 & 0.201 & 253.98 & 14.73 & 30.585 & 106.33 & 203.14 & 49.381 & $18.638(25.53)$ \\
\hline & $\mathrm{SE} \pm$ & $0.3138(0.19)$ & 0.73 & 0.00537 & 0.0058 & 1.1547 & 0.09 & 0.3238 & 0.31148 & 0.6305 & 2.883 & $0.3997(0.29)$ \\
\hline & CD at $5 \%$ & $0.9245(0.57)$ & 2.16 & 0.01584 & 0.01736 & 3.4011 & 0.27 & 0.9539 & 0.91745 & 1.8573 & 8.4918 & $1.1774(0.86)$ \\
\hline & CD at $1 \%$ & $1.2624(0.78)$ & 2.95 & 0.0216 & 0.0237 & 4.645 & 0.37 & 1.3028 & 1.253 & 2.537 & 11.598 & $1.6079(1.18)$ \\
\hline
\end{tabular}


Medium and small sized dal have maximum expansion in volume of cooked dal than big sized dal, increase in volume ranging from 162.2 to 200 per cent reported by Sankaran and Shrinivasan (1963). Similarly, in case if thickness of dal ranged with $0.170-0.225$ $\mathrm{cm}$ with an average value of $0.201 \mathrm{~cm}$. Out of eighteen hybrids, four hybrids were with thickness of $0.225 \mathrm{~cm}$ and the hybrids ICPH 2751 and ICPH 3462 exhibited lowest value for thickness of dal $(0.170 \mathrm{~cm}$ and $0.170 \mathrm{~cm}$ respectively). Variation in dal recovery and size of dal has been reported by Sankaran and Srinivasan (1963) and Ramakrishnalah and Kurien (1985).

With respect to the range of number of $d a l$ in $10 \mathrm{~g}$ (Table 5) was 219.50 to 302.00 with an average value of 253.98. The check Maruti (302.00) followed by hybrid ICPH 3472 recorded highest mean performance for number of dal in $10 \mathrm{~g}$ (280.50) however, ICPH 3461 with least number of dal in $10 \mathrm{~g}$ (219.50). Likewise, the range for volume of $10 \mathrm{~g} \mathrm{dal}$ was 13.15 to $15.55 \mathrm{cc}$ with an average value of $14.73 \mathrm{cc}$. Among eighteen hybrids, ICPH 3472 obtained highest volume of $10 \mathrm{~g}$ dal $(15.55 \mathrm{cc})$ while ICPH 3462 showed lowest volume of $10 \mathrm{~g}$ dal $(13.15 \mathrm{cc})$. Similarly, the range for weight of cooked dal was 28.75 to $32.50 \mathrm{~g}$ with an average value of 30.58 g. The check Asha showed highest weight of cooked dal (32.50 g) followed by check variety Maruti (32.35) and hybrid ICPH 3494 (32.08 g) whereas, ICPH 3933 obtained lowest weight of cooked dal $(28.75$ g). With respect to per cent increase in volume ranged from 84.05 to 133.07 per cent with an average value of 106.33 per cent. Among total eighteen hybrids and checks, the genotype ICPH 3462 recorded highest value for per cent increase in volume $(133.07 \%)$ while, the hybrid ICPH 3472 showed minimum value for per cent increase in volume $(84.05 \%)$. Per cent increase in weight (Table 5) was ranged from 182.50 to
223.50 per cent with an average value of 203.14 per cent. The genotype ICPH 3494 recorded highest per cent increase in weight $(223.50 \%)$ however, the lowest per cent increase in weight observed in the genotype ICPH 3464 (182.50 \%). Similarly, time taken for cooking ranged from 35.50 to $65.50 \mathrm{~min}$ with an average value of $49.381 \mathrm{~min}$. The hybrid ICPH 3494 required maximum time for cooking (65.50 min) whereas, ICPH 3464 (35.50 min) required less time for cooking. The cooking time variation has been reported by Shrivastava and Shrivastava (2006).

Likewise, the range for protein content was 13.81 to 22.11 per cent with an average value of 18.638 per cent. Among all genotypes, ICPH 3491 recorded highest rate of protein content (22.11 per cent) however, the hybrid ICPH 2673 (13.81 per cent) obtained lowest level of protein content. The results of the present study indicated that the seven promising hybrids viz. ICPH 3381, ICPH 2751, ICPH 2673, ICPH 3341, ICPH 3337, ICPH 3337 and ICPH 3359 need to be multiply on large scale at multi location for the benefit of the farmer.

\section{References}

Patel, M.P., Tikka, S.B.S., Prajapati, B.H. and Patel, G.S. 2005. Stability analysis for seed yield of pigeonpea parents and their hybrids. Indian J. Pulses Res., 18(2): $158-160$.

Phad, D.S., I.A. Madrap and V.A. Dalvi. 2009. Heterosis in relation to combining ability effects and phenotypic stability in pigeonpea. $J$. Food legumes, 22(1): 59-61.

Ramakrisnaiah, N. and P.P. Kurien 1983. Variabilities in the dehulling characteristics of pigeonpea (Cajanus cajan L.) cultivars. J. Food Sci. Technol., (India): 20:287.

Sankaran, S. and V. Srinivasan. 1963. Evaluation of redgram types for 
cooking quality. Madras Agric. J., 50: 470-471.

Sarode, S.B., M.N. Singh and U.P. Singh. 2009. Heterosis in long duration pigeonpea (Cajanus cajan (L.) Mill sp.). Int. J. Plant Sci., 4(1): 106-108.
Indian agriculture. Electronic J. Plant Breed., 1(4): 1107-1117.

Shrivastava, R.P. and G.K. Srivastava. 2006. Genotypic variation in nutritional composition of pigeonpea seeds. Indian J. pulses Res.., 19(2): 244-245.

Saxena, K.B. and Nadarajan, N. 2010.

Prospects of pigeonpea hybrids in

\section{How to cite this article:}

Priyanka S. Gaikwad, Dipali P. Thakare and Mehtre, S.P. 2017. Exploitation of Promising Hybrids on the Basis of Heterosis and Quality Parameters of Pigeonpea (Cajanus cajan (L.) Millsp.). Int.J.Curr.Microbiol.App.Sci. 6(3): 1205-1213.

doi: https://doi.org/10.20546/ijcmas.2017.603.140 